\title{
A simple naphthalimide-based receptor for selective recognition of fluoride anion
}

\author{
Arvind Misra,* Mohammad Shahid, Pratibha Dwivedi, Priyanka Srivastava \\ Rashid Ali, and Syed S. Razi \\ Department of Chemistry, Faculty of Science, Banaras Hindu University, \\ Varanasi - 221 005. India \\ E-mail: arvindmisra2003@yahoo.com
}

\section{This manuscript is dedicated to Professor Richard R. Schmidt in honor of his outstanding contributions to chemistry}

\begin{abstract}
Synthesis of a simple fluorescent naphthalimide based receptor 4-aminobenzyl- $N$-methyl-1,8naphthalimide $\mathbf{3}$ was carried out as a selective fluoride ion sensor. In acetonitrile, interaction of $\mathbf{3}$ with different anions such as, $\mathrm{AcO}^{-}, \mathrm{F}^{-}, \mathrm{Cl}^{-}, \mathrm{Br}^{-}, \mathrm{I}^{-}$, and $\mathrm{SCN}^{-}$revealed significant fluorescence quenching only with the $\mathrm{F}^{-}$anion. In the presence of the fluoride anion, the color of the solution changed from a fluorescent green to violet and this was visible to the naked eye. The probable mode of sensing mechanism by photo-induced electron transfer (PET) reaction is attributed to deprotonation of acidic NH proton in the presence of fluoride which was confirmed by change in optical properties intramolecular charge transfer (ICT) and ${ }^{1} \mathrm{H}$ NMR spectral data analysis. The Job's plot analysis displayed a 1:1 stoichiometry for interaction between $\mathbf{3}$ and $\mathrm{F}^{-}$. The extent of fluorescence quenching was estimated by Stern-Volmer plot.
\end{abstract}

Keywords: 4-Aminobenzyl- $N$-methyl-1,8-naphthalimide, chemosensor

\section{Introduction}

The selective recognition and sensing of anions via a synthetic organic scaffolds as a sensitive fluorescent chemosensor, containing a suitable receptor site and fluorophore have received considerable attention of chemists in past decades. ${ }^{1}$ Fluoride anion plays significant role in chemical, environmental and biochemical processes, ${ }^{2-4}$ hence their recognition is important. The non-covalent ionic recognition generally, governed by the energy of the receptor-anion interaction, geometry, basicity of the employed anion and nature of the solvent systems. In fact, a strong hydrogen bonding interaction is facilitated by the interaction with anions such as fluoride of relatively high electronegativity. Additionally, more impetus is realized on strategies that can 
demonstrate both chromo and fluorogenic changes upon interaction with anions utilizing binding site-signaling approach. ${ }^{5-7}$ To make recognition process sensitive, simple and convenient to naked-eye chemosensors have been developed containing a chromophore and anion binding site that is capable to establish selective interaction with the specific anion either by directional hydrogen bonding or by donation of one or more hydrogen of $\mathrm{NH}$ fragment (deprotonation).

Of the various analytical techniques to make the ionic recognition easier fluorescence based methods are demanding as it offers more selectivity and sensitivity. ${ }^{5-7}$ Based on different phenomenon of photophysics ${ }^{8-10}$ various synthetic organic scaffolds containing a suitable receptor site such as, urea, ${ }^{11}$ thiourea, ${ }^{12}$ amides, ${ }^{13}$ macrocyclic ammonium/guanidinium, ${ }^{14}$ phenylhydrazone, ${ }^{15}$ indole,${ }^{16}$ pyrrole,,${ }^{17,18}$ phenol, ${ }^{19}$ 1,2-diaminoanthraquinone ${ }^{20}$ and 4-amino-1,8naphthalimide derivatives ${ }^{21}$ have been designed and developed for favorable naked-eye sensitive, ion-receptor interaction studies. Although much has been achieved however, the chromo and fluorogenic chemosensors that are capable to detect fluoride specifically are limited in number. ${ }^{22,23}$ Keeping these perspectives in mind we have previously developed a thiourea-based colorimetric sensor that was able to recognize both fluoride and acetate ions. ${ }^{24}$ In the present report we designed a very simple naphthalimide based sensor $\mathbf{3}$ which could detect $\mathrm{F}^{-}$selectively and of almost the same sensitivity as reported by others.

\section{Results and Discussion}

\section{Synthesis and optical behavior of 3}

The simple naphthalimide-based chemosensor, 4-aminobenzyl- $N$-methyl-1,8-naphthalimide $\mathbf{3}$ was synthesized as reported previously ${ }^{25}$ in high yield (Scheme 1). A yellow colored solid model compound $\mathbf{4}$ was obtained by reacting 3 in the presence of sodium hydride $(\mathrm{NaH})$ with methyl iodide (MeI) in tetrahydrofuran (THF). In the present charge transfer signaling system naphthalimide moiety act as a fluorophore and the extended electron donating benzylamine unit is expected to generate an associated prominent optical signal in the recognition process. The $\mathrm{N}-$ $\mathrm{H}$ subunit appended in between naphthalimide and benzylamine units is speculated to facilitate receptor-ion interaction specifically and upon interaction with anions of sufficient basicity such as, $\mathrm{F}^{-}$would lead to a significant change in the optical properties of naphthalimide chromophore unit due to enhance charge density probably, as a result of deprotonation of $\mathrm{N}-\mathrm{H}$ fragment. Thus, the ultimate negative charge develop on the receptor would modulate both UV-Vis and fluorescence spectra due to change in intramolecular charge transfer (ICT) and photoinduced electron transfer (PET) reactions (Figure 1). Consequently, the ultimate prominent visible color change from a yellow-green to a red in the solution of $\mathbf{3}$ was found sensitive to the naked eye. Further, the placement of benzyl group close to ion-receptor site will allow limited opportunity to a particular anion for interaction and make the sensing event selective. The crystal structure displayed the geometry of molecule and availability of exposed receptor site to interact with subjected anions and probability of electron transfer from receptor to electron deficient naphthalimide chromophoric unit. 
<smiles>O=C1OC(=O)c2ccc(Br)c3cccc1c23</smiles>

1 (i)<smiles>CN1C(=O)c2cccc3c(Br)ccc(c23)C1=O</smiles>

(ii)<smiles>CN1C(=O)c2cccc3c(NCc4ccccc4)ccc(c23)C1=O</smiles>

3<smiles>CN1C(=O)c2cccc3c(N(C)Cc4ccccc4)ccc(c23)C1=O</smiles>

4

Scheme-1. Synthesis of chemosensor 3. (i) $\mathrm{MeNH}_{2} / \mathrm{EtOH} / \mathrm{reflux}$ (ii) $\mathrm{Bz}-\mathrm{NH}_{2} / \mathrm{Pyridine} / \mathrm{TEA} /$ reflux (iii) $\mathrm{THF} / \mathrm{NaH} / \mathrm{MeI} /$ reflux.
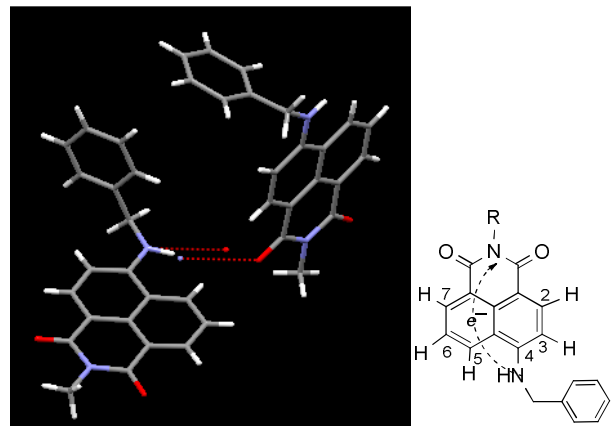

Figure 1. Crystal structure shows geometry of chemosensor $\mathbf{3}$ and structure demonstrates a probable electron transport mechanism.

\section{UV-Vis absorption studies}

The chemosensor 3 possess large dipole moment due to a strong intramolecular charge transfer (ICT) excited state. The UV-vis electronic transition spectrum of $\mathbf{3}\left(2 \times 10^{-5} \mathrm{M}\right)$ in acetonitrile displayed two characteristic absorption bands at $427 \mathrm{~nm}\left(\varepsilon 19250 \mathrm{M}^{-1} \mathrm{~cm}^{-1}\right)$ and $279 \mathrm{~nm}$ probably due to ICT state and a high energy $\pi \rightarrow \pi^{*}$ electronic transitions respectively (Figure 2 ). In order to understand the selective and sensitive anion binding affinity of $3 \mathrm{UV}$-vis absorption and fluorescent spectra were acquired in acetonitrile. Upon addition of different anions (5 equiv) such as, $\mathrm{AcO}^{-}, \mathrm{F}^{-}, \mathrm{I}^{-}, \mathrm{Cl}^{-}, \mathrm{Br}^{-}$and $\mathrm{SCN}^{-}$(as their tetrabutylammonium salts) the characteristic absorption spectra modulated significantly only in the presence of $\mathrm{F}^{-}$and two new bands appeared at 530 and $340 \mathrm{~nm}$ respectively, attributed to the charge transfer reaction from receptor site to naphthalimide moiety. The addition of other anions exhibited no significant change in the absorption spectra of $\mathbf{3}$, thus suggesting the high selectivity for $\mathrm{F}^{-}$anion. UV-Vis titration experiment was performed to understand the binding affinity of $\mathbf{3}$ with fluoride anion. Figure 3 depicts that upon gradual addition of $\mathrm{F}^{-}$ions (0-5 equiv) absorption bands centered at 427 and $279 \mathrm{~nm}$ were reduced and two new bands at 530 and $340 \mathrm{~nm}$ were appeared concomitantly. The isosbestic points which appeared at 468 and $370 \mathrm{~nm}$ suggested the presence of more than one species in the medium. Thus, as expected, the ICT state of $\mathbf{3}$ modulated in the 
presence of $\mathrm{F}^{-}$and a prominent naked-eye sensitive color changed from a yellow-green to red (Inset, Figure 2). The Job's plot (Inset, Figure 3) analysis revealed a 1:1 stoichiometry for a complexation between $\mathbf{3}$ and $\mathrm{F}^{-}$. The association constant $\left(K_{\text {ass }}\right)$ determined by non-linear fitting ${ }^{26}$ of absorption titration curve was found to be $K_{\text {ass }} 1.24 \times 10^{4} \mathrm{M}^{-1}$ with detection limit of $20 \mu \mathrm{M}$ concentration.

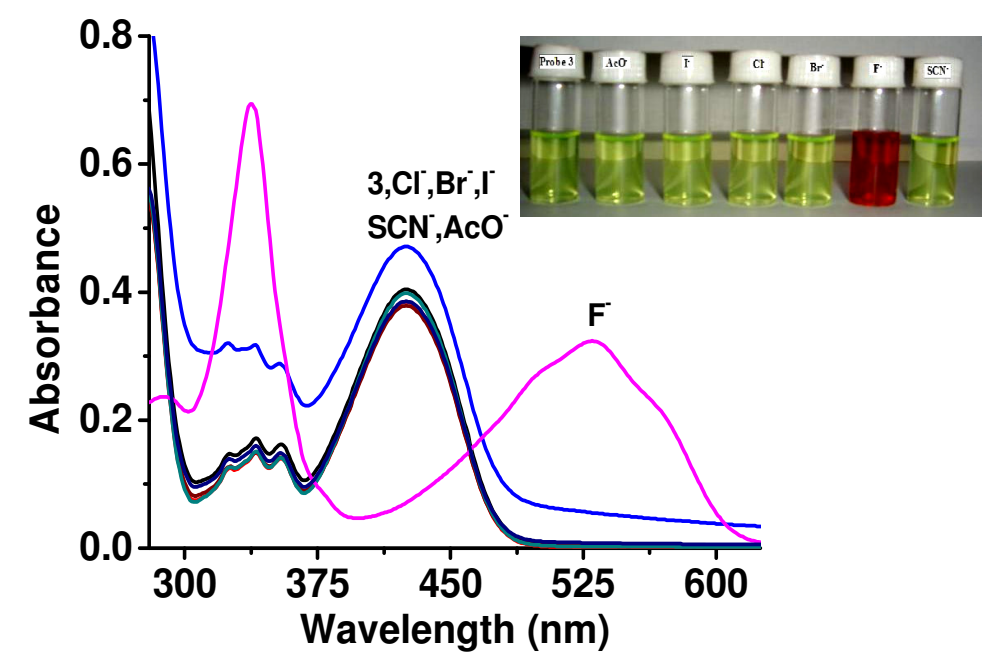

Figure 2. Changes in UV-Vis absorption spectra of chemosensor $3(20 \mu \mathrm{M})$ upon addition of different anions (5.0 equiv). Inset illustrates visible color change for chemosensor $\mathbf{3}$ after addition of different anions in acetonitrile.

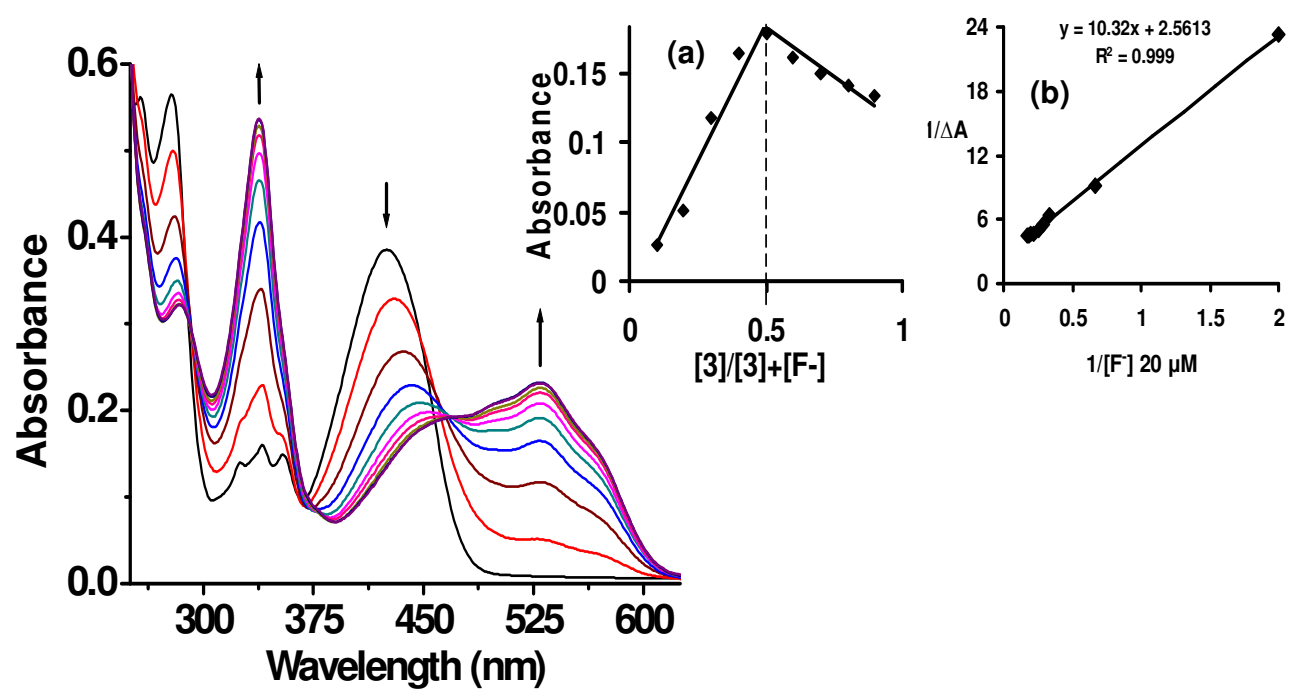

Figure 3. UV-Vis titration spectra of chemosensor $3(20 \mu \mathrm{M})$ upon sequential addition of $\mathrm{F}^{-}(0-5$ equiv). Inset: (a) Job's plot and (b) Benesi-Hildebrand plot. 
The variation in charge transfer $(\mathrm{CT})$ reaction upon interaction with $\mathrm{F}^{-}$may be attributed to deprotonation of acidic proton $(\mathrm{N}-\mathrm{H})$ present at $\mathrm{C}-4$ position of naphthalimide unit or through hydrogen bonding interaction. ${ }^{5}$ To understand that, strong bases such as tetrabutylammonium hydroxide $(\mathrm{TBAOH})$, sodium hydride $(\mathrm{NaH})$ and triethylamine (TEA) were added to a solution of 3. The color of solution changed to red upon addition of TBAOH and $\mathrm{NaH}$ while no such variation in color could be observed upon addition of TEA. However, on addition of methanol (a protic solvent) the original yellow-green color reappeared slowly, thereby suggesting reversibility in deprotonation of acidic proton $(\mathrm{N}-\mathrm{H})$ and hence probable mode of interaction of $\mathrm{F}^{-}$anion selectively leading to the formation of negatively charged naphthalimide ( $\mathrm{Naph}^{-}$) and $\mathrm{HF}_{2}{ }^{-}$species (Scheme 1) in the medium, subsequently. Thus, the enhanced charge density on the naphthalimide unit due to push-pull character led to colorimetric changes and modulation in the electronic transition bands in which the intensity of absorption band at $427 \mathrm{~nm}$ and $530 \mathrm{~nm}$ 'switched-off' and 'switched-on' respectively. The above discussed results also indicate the occurrence of equilibrium between the host and guest molecule in which a proton is abstracted from $\mathrm{N}-\mathrm{H}$ fragment of $\mathbf{3}$ and bridges fluoride ions to result in the hydrogen difluoride self complex as shown in the following equation.

$$
\left[\mathrm{LH}+2 \mathrm{~F}^{-} \rightarrow \mathrm{L}^{-}+\mathrm{HF}_{2}^{-}\right]
$$

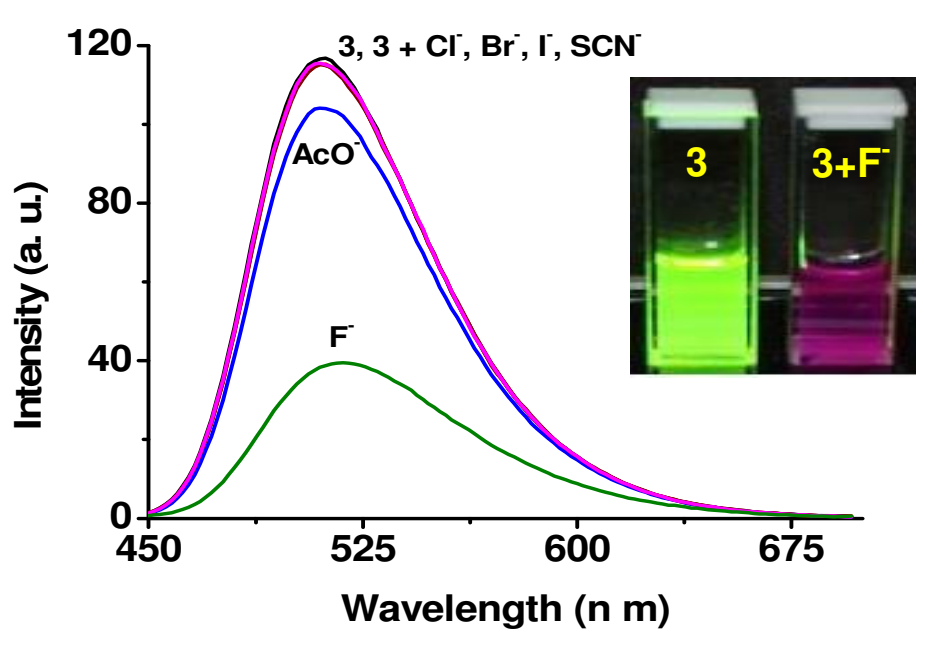

Figure 4. Change in emission spectra for $3(10 \mu \mathrm{M})$ upon addition of $\mathrm{AcO}^{-}, \mathrm{Cl}^{-}, \mathrm{I}^{-}, \mathrm{SCN}^{-}, \mathrm{Br}^{-}$, and $\mathrm{F}^{-}$(20 equiv) (as their tetrabutylammonium salts) in acetonitrile. Inset shows change in color of solution upon interaction with $\mathrm{F}^{-}$under UV light.

\section{Fluorescence studies}

In acetonitrile, upon excitation at $427 \mathrm{~nm}$, probe 3 displayed emission band at $512 \mathrm{~nm}(\Phi 0.58$ with respect to fluorescein, as standard). Upon addition of tested anions (20 equiv) to a solution 
of probe 3 fluorescence quenching ( 3 times) occurred only with $\mathrm{F}^{-}$anion $\left(\Phi_{3+\mathrm{F}^{-}} 0.21\right.$ with respect to fluorescein, as standard). However, interaction of $\mathbf{3}$ with other tested anions failed to exhibit any significant change in the emission spectra (Figure 4). The fluoride ion sensitivity of $\mathbf{3}$ could be understood by competitive anion interaction study in which the extent of fluorescence quenching remained unaffected upon addition of $\mathrm{F}^{-}$to the solution of $\mathbf{3}$ containing other anions and oppositively, after the addition of tested anions to a solution of 3 . $\mathrm{F}^{-}$. The binding affinity of 3 was further examined through fluorescence titration spectral data analysis. Figure 5 shows that upon increasing the concentration of $\mathrm{F}^{-}$(0-20 equiv) to a solution of $\mathbf{3}$ the emission band centered at $512 \mathrm{~nm}$ reduced gradually with a bathochromic shift of $9 \mathrm{~nm}$ and the color of solution changed from a fluorescent green to violet (under UV light Inset, of Figure 4). The Job's plot analysis revealed a 1:1 stoichiometry for equilibrium between the $\mathbf{3}$ and $\mathrm{F}^{-}$. The association constant calculated by non linear fitting of fluorescence titration data was found to be $K_{\text {assoc }} 1.0 \times$ $10^{4} \mathrm{M}^{-1}$. The extent of fluorescence quenching was estimated quantitatively by obtaining SternVolmer $(S-V)$ plot (Figure $5 b$ ) between the intensity ratio, $I_{o} / I$ and concentration of $\mathrm{F}^{-}$anions. An almost straight line $\left(R^{2} 0.9919\right)$ with quenching constant, $K_{\mathrm{S}-\mathrm{V}} 1.7 \times 10^{4} \mathrm{M}^{-1}$, further suggested the quenching process in the present anion sensing event due to an enhanced photoinduced electron transfer (PET) reaction. To support the mechanism of sensing a model receptor 4 which do not contain free $\mathrm{N}-\mathrm{H}$ functionality at $\mathrm{C}-4$ position, was subjected to anion interaction studies under similar experimental condition. The insignificant change in the absorption and emission spectra of $4(20 \mu \mathrm{M})$ upon addition of tested anions (20 equiv) supported the sensing events and possible mode of interaction of fluoride anion with $\mathrm{NH}$ fragment (Figure 6).
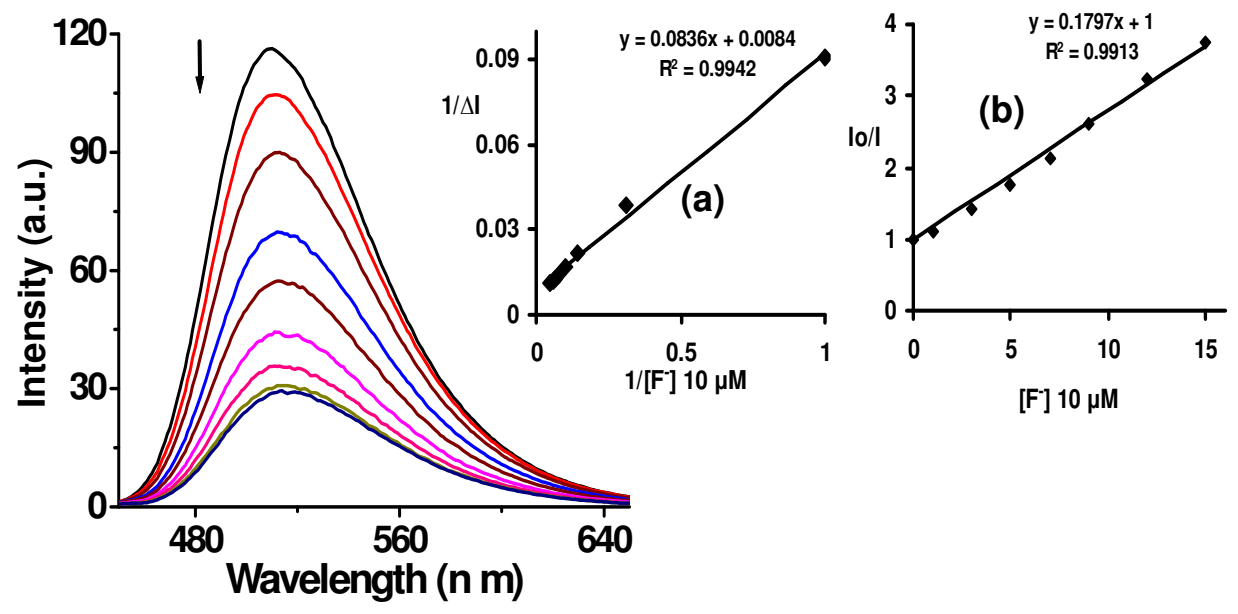

Figure 5. Fluorescence titration spectra of $3(10 \mu \mathrm{M})$ with $\mathrm{F}^{-}$anions ( $0-20$ equiv) in acetonitrile upon excitation at $427 \mathrm{~nm}$. Inset shows (a) Benesi-Hildebrand and (b) Stern-Volmer plots. 

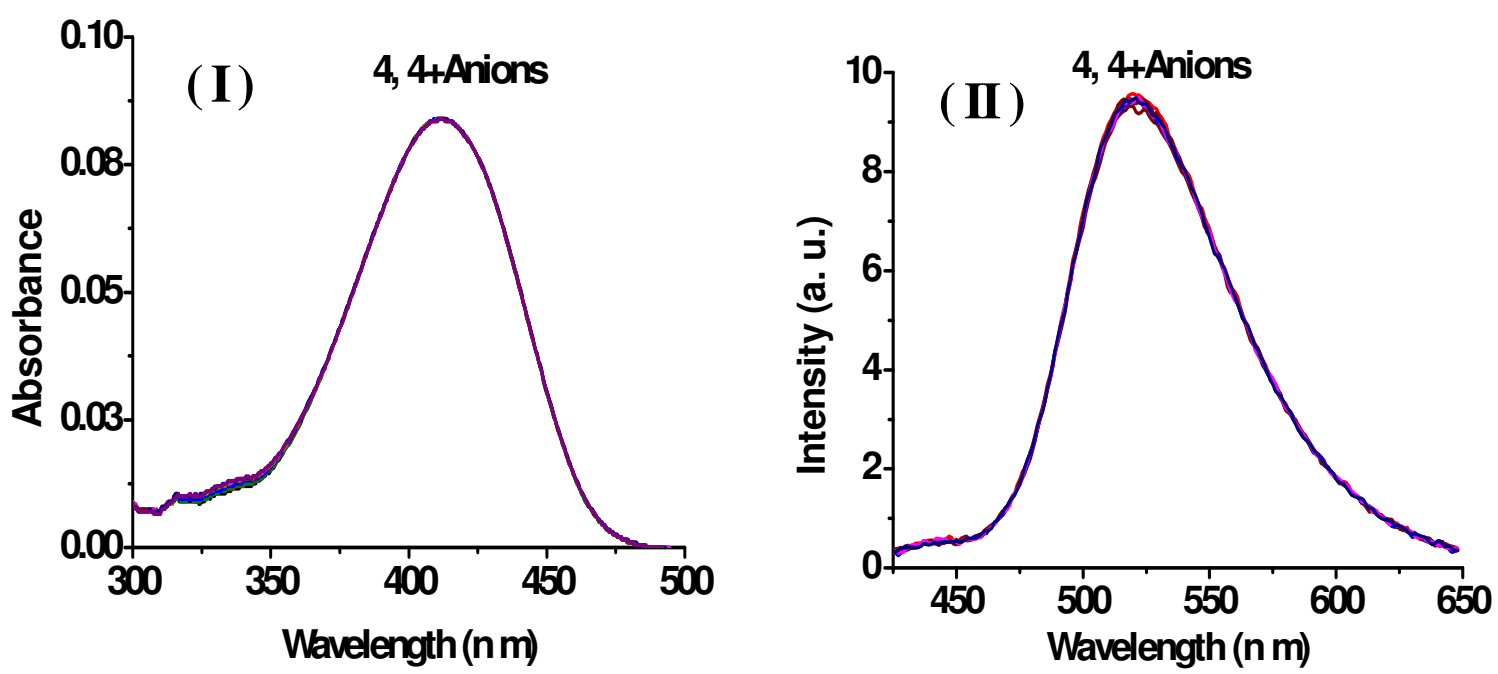

Figure 6. (I) Absorption and (II) emission spectra of $4(20 \mu \mathrm{M})$ upon addition of various anions (20 equiv) in acetonitrile at $409 \mathrm{~nm}$ excitation.

\section{pH Studies}

The probability of photoinduced electron transfer reaction was further ascertained by acid-base titration experiment and fluorescence spectra of $\mathbf{3}$ under different $\mathrm{pH}$ conditions were analyzed. It can be seen from Figure 7 (I) that upon increasing the $\mathrm{pH}$ of the medium from 1.0 to 5.0 there was a gradual increase in the relative fluorescence intensity. However, in the pH range 6.0 to 7.0 the enhanced fluorescence intensity decreased abruptly while, in alkaline $\mathrm{pH}$ conditions (in the range 7.0 to 12.0 ) the fluorescence intensity of $\mathbf{3}$ decreased significantly (Figure 7, II). Thus, suggesting about the change in fluorescence intensity in two successive steps corresponding to the $\mathrm{pH}$ conditions. First, in acidic medium (below $\mathrm{pH}$ 6.0) at $\mathrm{pH} 1$ - 2, fluorescence intensity was relatively less. This increased gradually within the $\mathrm{pH}$ range $3-6$. The sharp fluorescence recovery could be attributed to protonation of the amino function of naphthalimide unit and hence, arrest in PET process. Secondly, when the $\mathrm{pH}$ of medium raised to alkaline conditions fluorescence decreased gradually due to the rapid PET reaction. Thus, the observed relative changes clearly supported the involvement of photoinduced electron transfer and proton transfer mechanism in the ion binding event and consequently change in the color of sensor solution (Inset, Figure 4).

Moreover, Figure 8 shows that the change in relative fluorescence intensity with respect to the $\mathrm{pHs}$ is almost sigmoidal therefore, suggesting about the proton-triggered fluorescence recovery, as expected in a typical PET system. The enhanced fluorescence in the $\mathrm{pH}$ range 1.0 to $5.0(\mathrm{pKa} 4.1$ at $\mathrm{pH} 5.0)$ supports protonation of $\mathrm{N}-\mathrm{H}$ fragment, whereas in alkaline conditions there was a continuous decrease in the intensity which was found maximum at $\mathrm{pH} 9.0(\mathrm{pKa}$ 8.86). Therefore, suggesting about the existence of an equilibrium between protonated and 
deprotonated species in the medium and the electron transfer originate from the aminobenzyl to naphthalimide unit.
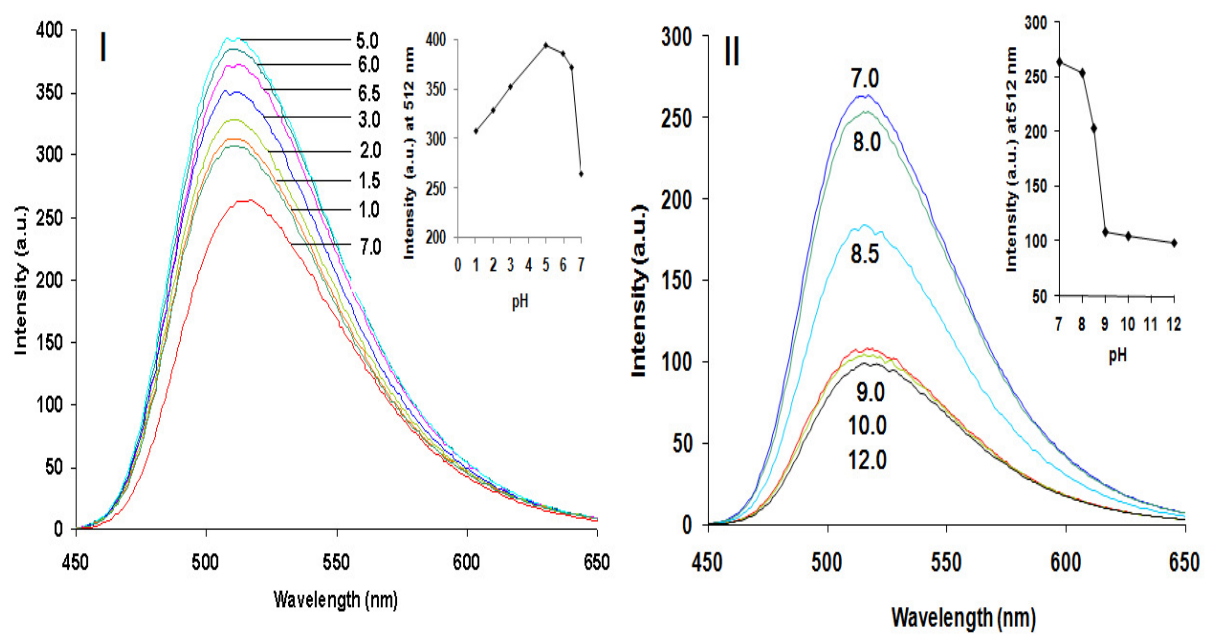

Figure 7. Change in fluorescence intensity for $3(10 \mu \mathrm{M})$; (I) $\mathrm{pH}, 1.0$ - 7.0 and (II) $\mathrm{pH}, 7.0$ 12.0. Inset: Shows relative change in intensity at different $\mathrm{pHs}\left(\lambda_{\mathrm{em}}\right.$ at $\left.512 \mathrm{~nm}\right)$ upon excitation at $427 \mathrm{~nm}$ in acetonitrile.

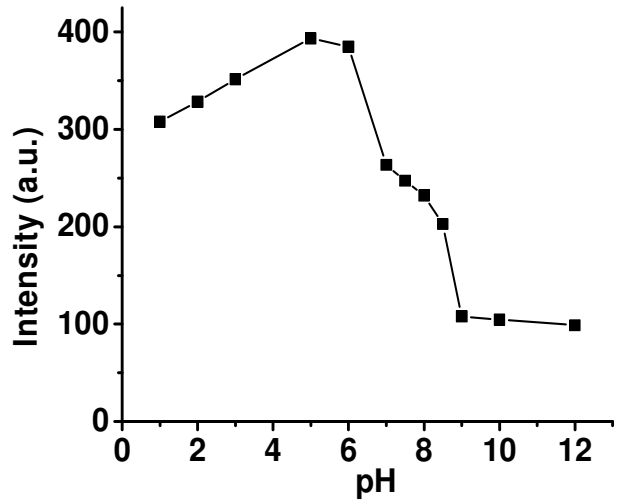

Figure 8. Change in fluorescence intensity for $3(10 \mu \mathrm{M})$ under $\mathrm{pH}$ conditions $1-12$ in acetonitrile.

${ }^{1}$ H NMR studies: ${ }^{1} \mathrm{H}$ NMR titration spectral studies were carried out in DMSO- $d_{6}$ solution to corroborate the subsequent changes in optical behavior probably due to the deprotonation of acidic proton of NH fragment (Figure 9). ${ }^{1} \mathrm{H}$ NMR spectrum of $\mathbf{3}$ showed typical resonances in the range $\delta 9.0$ and $6.5 \mathrm{ppm}$ corresponding to naphthalimide and benzyl rings and a signal at $\delta$ 8.52 may be attributed to the 4-amino proton. Upon addition of 0.5 equiv of $\mathrm{F}^{-}$(as TBAF salt) the resonances for $\mathrm{H} 3, \mathrm{H} 5, \mathrm{H} 6$ and $\mathrm{H} 7$ protons were shifted toward high and low fields 
respectively. The $\mathrm{H} 3(6.74 \mathrm{ppm}, J 8.7 \mathrm{~Hz})$ and $\mathrm{H} 5(8.23 \mathrm{ppm}, J 8.4 \mathrm{~Hz})$ protons of naphthalimide unit were substantially shifted toward highfield to appear at $\delta 6.63$ and $8.14 \mathrm{ppm}$ respectively, and were gradually broadened after the addition of 2.5 equiv of $\mathrm{F}^{-}$. The overlapped $\mathrm{NH}$ proton (with $\mathrm{H} 2$ ) on addition of fluoride ion separated and shifted toward highfield to appear as singlet at $\delta 8.36 \mathrm{ppm}$. Upon increasing the amount of fluoride ions (1.5 equiv) the $\mathrm{NH}$ resonance become broadened and shifted toward more highfield region and simultaneously a new signal at $\delta 16.3 \mathrm{ppm}$ was appeared due to the formation of a new ion pair complex (bifluoride ion) $\mathrm{HF}_{2}^{-}$ species in the reaction medium ${ }^{27}$ (extended stacked ${ }^{1} \mathrm{H}$ NMR spectra, Figure 9). The resonance signal for the formation of $\mathrm{HF}_{2}{ }^{-}$complex became dominant on increasing the amount of $\mathrm{F}^{-}$(2.5 equiv). The $\mathrm{H} 7$ and $\mathrm{H} 3$ protons of the naphthalimide unit in the presence of fluoride ions broadened and shifted toward low and high fields respectively however, benzyl ring protons almost remained unchanged.

Thus, the ${ }^{1} \mathrm{H}$ NMR titration studies clearly suggested the deprotonation of 4-amino proton, in the sensing event with the formation of $\mathrm{HF}_{2}^{-}$complex that increases the electron density on the naphthyl ring and concomitant upfield shift for the respective protons due to increased shielding effect. The complete disappearance of $\mathrm{NH}$ signal in the presence of fluoride ion clearly suggested that the deprotonation of 4-amino proton unit has occurred which obviously, enhanced the PET reaction and consequently, diminished fluorescence and respective colorimetric changes in the medium. ${ }^{28,29}$

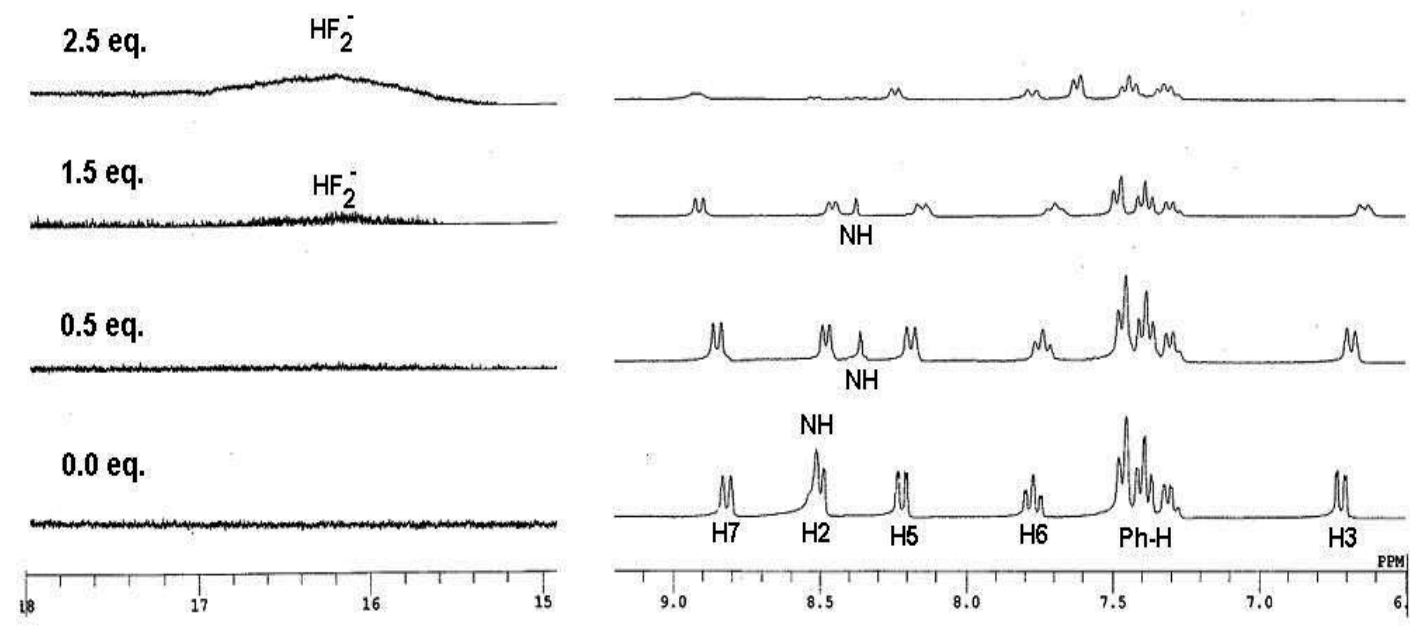

Figure 9. Partial Stack plot of ${ }^{1} \mathrm{H}$ NMR titration spectra for $3\left(1.2 \times 10^{-2} \mathrm{M}\right)$ after addition of $\mathrm{F}^{-}$ $\left(0-2.5\right.$ equiv) in DMSO- $d_{6}$ at $25{ }^{\circ} \mathrm{C}$. (For convenience ${ }^{1} \mathrm{H}$ NMR spectra have modified to show changes in specific $\delta$ ppm region).

\section{Conclusions}

We have developed a simple naphthalimide-based chemosensor for selective detection of $\mathrm{F}^{-}$in acetonitrile solution. The simple and highly colored chemosensor has demonstrated 'naked-eye' 
sensing event for $\mathrm{F}^{-}$involving photoinduced electron transfer mechanism. The ${ }^{1} \mathrm{H}$ NMR spectroscopic data confirmed the deprotonation of the NH fragment in the presence of fluoride ion.

\section{Experimental Section}

General. All the reagents were purchased from Merck and Sigma-Aldrich and were used without any further purification. To study the optical properties of chemosensor tetrabutylammonium (TBA) salts of different anions were utilized. Both UV-vis and fluorescence spectra have been recorded in acetonitrile (ACN) solution. ${ }^{1} \mathrm{H}$ NMR spectra were recorded in DMSO- $d_{6}$ solvent. IR spectra in $\mathrm{KBr}$ were recorded on a Varian-3100 FT-IR spectrophotometer. ${ }^{1} \mathrm{H}$ NMR spectra (chemical shifts in $\delta \mathrm{ppm}$ ) were recorded on a JEOL AL 300 FT-NMR (300 MHz) spectrometer, using TMS as internal standard. The UV-Vis absorption spectra were recorded on Shimadzu 1700 spectrophotometer using a quartz cuvette (path length $1 \mathrm{~cm}$ ). Fluorescence spectra were recorded on a Cary Eclipse fluorescence spectrophotometer (Varian). Single crystal data were generated on X-ray diffractometer (Xcalibur, Oxford) and were analyzed through SHELX-97 and Mercury software. All the spectroscopic experiments were carried out at $25{ }^{\circ} \mathrm{C}$. Molar solutions for Probe $3\left(2 \times 10^{-5} \mathrm{M}\right)$ and tetrabutylammonium (TBA) salts of different anions (1.0 $\times 10^{-2} \mathrm{M}$ ) were prepared in anhydrous acetonitrile $(\mathrm{ACN})$ and utilized in all spectroscopic titration studies. Single crystal of sensor molecule was developed in chloroform-ether mixed solvent system under the cold condition. The binding stability of receptor or chemosensor for anions was investigated by UV-Vis absorption and emission spectroscopy in ACN. For absorption titration studies different equivalents of TBAF ( $6 \mu 11$ equiv) were added sequentially to a constant concentration of chemosensor $\left(3 \mathrm{ml}, 2 \times 10^{-5} \mathrm{~mol} \mathrm{~L}^{-1}\right)$. Fluorescence spectra of $\mathbf{3}$ (c $1 \times 10^{-5} \mathrm{~mol} \mathrm{~L}^{-1}$ ) in the absence and presence of different anions were recorded in ACN. Fluorescence titration studies were carried out by increasing amount of TBAF to the solution of 3. Quantum yield of chemosensor was estimated by a secondary method, ${ }^{30}$ utilizing equation (1) where $A_{s}$ and $A_{x}$ are the absorbance and $F_{s}$ and $F_{x}$ are integrated emission areas of standard and chemosensor respectively. Fluorescein has been used as a standard ${ }^{31}$ (quantum yield in ethanol is $0.79)$.

$$
\Phi_{\mathrm{x}}\left[\left(\mathrm{A}_{\mathrm{s}} \times \mathrm{F}_{\mathrm{x}}\right)\right] /\left[\left(\mathrm{A}_{\mathrm{x}} \times \mathrm{F}_{\mathrm{s}}\right)\right] \times \Phi_{\mathrm{s}}
$$

${ }^{1} \mathrm{H}$ NMR spectrum of chemosensor was recorded in DMSO- $d_{6}$. The change in ${ }^{1} \mathrm{H}$ NMR titration spectra was observed by addition of increasing equivalents of TBAF (in DMSO- $d_{6}$ ) to the solution of chemosensor 3 (c $1.27 \times 10^{-2} \mathrm{~mol} \mathrm{~L}^{-1}$, in DMSO- $\left.d_{6}\right)$. 


\section{Synthesis of 3 and 4}

4-Benzylamino- $N$-methyl-1,8-naphthalimide (3). Synthesis of 3 was carried out as reported previously. ${ }^{25}$ To a suspension of 4-bromo-1,8-naphthalic anhydride $(0.83 \mathrm{~g}, 3 \mathrm{mmol})$ in anhydrous ethanol $(10 \mathrm{ml})$ methylamine $(0.5 \mathrm{ml})$ was added and stirred the reaction mixture at 70 ${ }^{\circ} \mathrm{C}$ for $4 \mathrm{~h}$. After completion of the reaction as monitored on TLC, cold water $(25 \mathrm{ml})$ was added to the reaction mixture leading to formation of a precipitate that was filtered off. The precipitate was washed with $10 \%$ aqueous $\mathrm{Na}_{2} \mathrm{CO}_{3}$ solution followed by water and dried to obtain an off white color solid in $91 \%$ yield $(0.79 \mathrm{~g}, 2.7 \mathrm{mmol})$. Then, to a solution of 4-bromo- $N$-methyl-1,8naphthalimide $(0.58 \mathrm{~g}, 2 \mathrm{mmol})$ in anhydrous pyridine $(7 \mathrm{ml})$, benzylamine $(1 \mathrm{ml}, 30 \mathrm{mmol})$ and triethylamine $(100 \mu \mathrm{l})$ were added and reaction mixture was refluxed for $6 \mathrm{~h}$. After the complete reaction (as monitored on TLC), the solvent was evaporated under reduced pressure and cold water was added to the thick oil to precipitate out the desired product, filtered and dried in air. Crystallization in acetic acid afforded the compound as a yellow orange color solid in $75 \%$ yield $(0.47 \mathrm{~g}, 1.5 \mathrm{mmol}) . \mathrm{Mp} 160{ }^{\circ} \mathrm{C} . R_{\mathrm{f}} 0.45$ (hexane : EtOAc : 6:4, v/v). IR $\left(v_{\max }, \mathrm{cm}^{-1}\right): 3365,3025$, 2924, 1645, 1581, 1399, 1360, 1278, 773. ${ }^{1} \mathrm{H}$ NMR (300 MHz, DMSO-d $\left.d_{6}\right) \delta$ (ppm): 8.80 (d, 1H, $J 8.4 \mathrm{~Hz}$, naphthyl), 8.52 (br, 1H, NH), 8.49 (d, 1H, J $8.4 \mathrm{~Hz}$, naphthyl), 8.36 (d, 1H, J 7.8 Hz, naphthyl), 7.75 (t, $1 \mathrm{H}, J_{1} J_{2} 7.8 \mathrm{~Hz}$, naphthyl), 7.45 (d, 2H, J 7.2 Hz, Ar-H), 7.37 (t, 2H, $J_{1} 7.2$ $\left.\mathrm{Hz}, J_{2} 7.8 \mathrm{~Hz}, \mathrm{Ar}-\mathrm{H}\right), 7.29$ (t, 1H, J $\left.6.6 \mathrm{~Hz}, \mathrm{Ar}-\mathrm{H}\right), 6.74-6.71$ (d, 1H, J 8.7 Hz, naphthyl), 4.71 (d, $\left.2 \mathrm{H}, J 5.1 \mathrm{~Hz},-\mathrm{CH}_{2}\right), 2.14\left(\mathrm{~s}, 3 \mathrm{H},-\mathrm{CH}_{3}\right) .{ }^{13} \mathrm{C} \mathrm{NMR}\left(75 \mathrm{MHz}, \mathrm{CDCl}_{3}\right) \delta(\mathrm{ppm}): 26.08\left(\mathrm{CH}_{3}\right), 48.0$ (C-N), 104.9, 110.9, 120.3, 123.1, 124.8, 125.8, 127.7 (7 C-naphthyl), 128.1(C-Phenyl), 129.0 (2 C-Phenyl), 129.6 (2 C-Phenyl), 131.1, 134.3, (2 C-naphthyl), 137.0 (C-Phenyl), 148.9 (Cnaphthyl), 164.3,164.9 (2 C=O); Anal. Calcd. For $\mathrm{C}_{20} \mathrm{H}_{16} \mathrm{~N}_{2} \mathrm{O}_{2}$ (316.1): C, 75.93; H, 5.10; N, 8.86\%. Found: C, 75.62; H, 5.38, N, 8.93\%.

4-(-Benzylmethylamino)- $N$-methyl-1,8-naphthalimide (4). To a solution of 3 (0.1 g, 0.32 $\mathrm{mmol})$ in anhydrous THF $(5 \mathrm{ml})$, cold solution of $\mathrm{NaH}(0.023 \mathrm{~g}, 0.96 \mathrm{mmol})$ in anhydrous THF $(1 \mathrm{ml})$ was added and stirred the reaction mixture at room temperature for $30 \mathrm{~min}$. A solution of methyl iodide $(30 \mu \mathrm{l}, 0.48 \mathrm{mmol})$ was added to the reaction mixture and the mixture was refluxed for 3-4 h under a nitrogen atmosphere. The reaction mixture was cooled, filtered and diluted with chloroform $(8 \mathrm{ml})$ and subsequently washed with water and brine solution and dried over anhydrous $\mathrm{Na}_{2} \mathrm{SO}_{4}$. The chloroform was evaporated under reduced pressure to get compound 4 as a yellowish orange color solid in $77 \%$ yield $(0.08 \mathrm{~g})$. Mp145 ${ }^{\circ} \mathrm{C} . R_{\mathrm{f}} 0.18$ (hexane: EtOAc $9: 1, \mathrm{v} / \mathrm{v})$; IR $\left(v_{\max }, \mathrm{cm}^{-1}\right): 3047,2926,2857,1648,1579,1394,1357,1282,780 .{ }^{1} \mathrm{H}$ NMR (300 MHz, $\left.\mathrm{CDCl}_{3}\right) \delta(\mathrm{ppm}): 8.60\left(\mathrm{~d}, 1 \mathrm{H}, J 7.5 \mathrm{~Hz}\right.$, naphthyl), 8.52 (dd, 2H, $J_{1} 8.1 \mathrm{~Hz}, J_{2}$ $8.4 \mathrm{~Hz}$, naphthyl), 7.66 (t, $1 \mathrm{H}, J_{1}, J_{2} 7.8 \mathrm{~Hz}$, naphthyl), $7.38(\mathrm{~m}, 5 \mathrm{H}, \mathrm{Ar}-\mathrm{H}), 7.20$ (d, 1H, J 8.1 Hz, naphthyl), $4.55\left(\mathrm{~s}, 2 \mathrm{H},-\mathrm{CH}_{2}\right), 3.55\left(\mathrm{~s}, 3 \mathrm{H},-\mathrm{CH}_{3}\right), 2.97\left(\mathrm{~s}, 3 \mathrm{H},-\mathrm{CH}_{3}\right) .{ }^{13} \mathrm{C} \mathrm{NMR}(75 \mathrm{MHz}$, $\left.\mathrm{CDCl}_{3}\right) \delta$ (ppm): 26.83, 41.01, 61.39, 114.7, 115.3 , 123.0, 125.2, 125.6, 127.5, 128.7, 129.9, 130.4, 131.0, 132.4, 137.0, 156.3, 164.2, 164.8. Anal. Calcd. For $\mathrm{C}_{21} \mathrm{H}_{18} \mathrm{~N}_{2} \mathrm{O}_{2}$ (330.1): C, 76.34; H, 5.49; N, 8.48\%. Found: C, 76.38; H, 5.48, N, 8.23\%. 


\section{Acknowledgements}

We are thankful to the Council of Scientific and Industrial Research (CSIR), New Delhi for financial support and Fellowships (to, MS, PD, PS). Authors also acknowledge the University Grant Commission (UGC) and Department of Science and Technology (DST) New Delhi for DSA-CAS and FIST programs.

\section{References}

1. Paduka Ali, H. D.; Kruger, P. E.; Gunnlaugsson, T. New J. Chem. 2008, 32, 1153.

2. Kirk, K. L. Biochemistry of the Halogens and Inorganic Halides, Plenum Press: NY, 1991; p 58.

3. Riggs, B. L. Bone and Mineral Research; Annual 2, Elsevier: Amsterdam, 1983; p366.

4. Wiseman, A. Handbook of Experimental Pharmacology XX/2, Springer-Verlag: Berlin, 1990, p 48, part 2.

5. de Silva, A. P.; Gunarantane, H. Q. N.; Gunnlaugsson, T.; Huxley, A. J. M.; McCoy, C. P.; Rademacher, J. T.; Rice, T. E. Chem. Rev. 1997, 97, 1515.

6. Martinez-Manez, R.; Sancenon, F. Chem. Rev. 2003, 103, 4419.

7. de Silva, A. P.; Fox, D. B. Huxley, A. J. M.; Moody, T. S. Coord. Chem. Rev. 2000, 205, 41.

8. Paduka, H. D.; Kruger, P. E.; Gunnlaugsson, T. New J. Chem. 2008, 3, 1153.

9. Beer, P. D. Acc. Chem. Res. 1998, 31, 71.

10. Choi, K.; Hamilton, A. D. Angew. Chem. Int. Ed. 2001, 40, 3912.

11. Quinlan, E.; Matthews, S. E.; Gunnlaugsson, T. J. Org. Chem. 2007, 72, 7497.

12. Bonizzoni, M.; Fabbrizzi, L.; Taglietti, A.; Tiengo, E. Eur. J. Org. Chem. 2006, 3567.

13. Kang, S. O.; Hossain, Md. A.; Bowman-James, K. Coord. Chem. Rev. 2006, 250, 3038.

14. Niikura, K.; Metzger, A.; Anslyn, E. V. J. Am. Chem. Soc. 1998, 120, 8533.

15. Wang, Y.; Lin, H.; Shao, J.; Cai, Z-S.; Lin, H-K. Talanta 2008, 74, 1122.

16. Bates, G. W.; Triyanti, Light, M. E.; Albrecht, M.; Gale, P. A. J. Org. Chem. 2007, 72, 8921.

17. Sessler, J. L.; Barley, N. M.; Pantos, G. D.; Lynch, V. M. New J. Chem. 2007, 31, 646.

18. Gale, P. A.; Anzenbacher, P.; Sessler, J. L. Coord. Chem. Rev. 2001, 222, 57.

19. Winstanley, K. J.; Sayer, A. M.; Smith, D. K. Org. Biomol. Chem. 2006, 4, 1760.

20. Miyaji, H.; Sessler, J. L. Angew. Chem. Int. Ed. 2001, 40, 154.

21. Gunnlaugsson, T.; Kruger, P. E.; Jensen, P.; Pfeffer, F. M.; Hussey, G. M. Tetrahedron Lett. 2003, 44, 8909.

22. Gale, P. A. Coord. Chem. Rev. 2001, 213, 79.

23. Fabbrizzi, L.; Licchelli, M.; Mancin, F.; Pizzeghello, M.; Rabaioli, G.; Taglietti, A.; Tecilla, P.; Tonellato, U. Chem. Eur. J. 2002, 8, 94.

24. Misra, A.; Shahid, M.; Dwivedi, P. Talanta 2009, 80, 532.

25. Misra, A.; Shahid, M.; Dwivedi, P. Monatsh. Chem. 2009, 140, 1209. 
26. Connors, K. A.; Binding constants, $1^{\text {st }}$ Ed.; Wiley: New York, 1987.

27. Shenderovich, I. G.; Tolstoy, P. M.; Golubev, N. S.; Smirnov, S. N.; Denisov, G. S.; Limbach, H-H. J. Am. Chem. Soc. 2003, 125, 11710.

28. Pfeffer, F. M.; Lim, K. F.; Sedgwick, K.J. Org. Biomol. Chem. 2007, 5, 1795.

29. Esteban-Gomez, D.; Fabbrizzi, L.; Licchelli, M. J. Org. Chem. 2005, 70, 5717.

30. Kellogg, R. E.; Bennett, R. G. J, Chem. Phys. 1964, 41, 3042.

31. Eaton, D. F. Pure Appl. Chem. 1988, 60, 1107 